\title{
HBIM AND THE 20TH CENTURY STEEL BUILDING HERITAGE A PROCEDURE SUITABLE FOR THE CONSTRUCTION HISTORY IN ITALY
}

\author{
R. Morganti ${ }^{1}$, A. Tosone ${ }^{1}$, D. Di Donato ${ }^{1}$, M. Abita $^{1}$ \\ ${ }^{1}$ DICEAA, Department of Civil, Construction-Architectural and Environmental Engineering, \\ University of L'Aquila, Italy, (renato.morganti, alessandra.tosone, danilo.didonato, matteo.abita)@univaq.it
}

\section{Commission II}

KEY WORDS: HBIM, Italian Architectural Heritage, Steel, Modern Movement.

\begin{abstract}
:
The use of steel technologies in Italian architecture still represents an unexplored field of research, characterised by limited and fragmented episodes that reveal important design experimentations and relevant architectural results of the $20^{\text {th }}$ century. For this reason, the aim of the research consists of defining a HBIM methodological approach addressed to the study of modern steel architectures, considering their specific features and their hybrid constructive nature. Indeed these buildings are often characterized by a high level of industrial production of building components merged with the recovery of a craftsmanship tradition, particularly appearing at the scale of structure and envelope details. The balance between standardization and traditional techniques in production processes, leads to the definition of a HBIM method composed of three steps: an operational tools for existing buildings of $20^{\text {th }}$ century made of steel that could support the construction of building digital archives, the organisation of maintenance programs and possible transformative actions, avoiding the loss of this heritage sometimes caused by bad interventions that deeply change original and valuable features of these architectures.
\end{abstract}

\section{ITALIAN ARCHITECTURAL HERITAGE MADE OF STEEL, AN ONGOING RESEARCH}

In Italy, only a limited number of studies has attempted to connect and interpret through a systematic approach the history of iron and steel constructions during the $20^{\text {th }}$ century, with the aim of organizing the sequence of events into an extended multi-disciplinary framework, encompassing the main actors of the building process, as well as the methodological and processual aspects needed to provide support and control to possible transformative actions.

In the country, between the first and second half of $20^{\text {th }}$ century, the use of steel technologies represented a field of research and design experimentation, constrained to a limited number of fragmented episodes, as a consequence of national events and the country's cultural background. The reconstruction of the historical and technical design aspects of the use of steel in architecture, and the innovative solutions that such implementations entailed, could represent an opportunity to understand the participation of Italian culture to the wider topic of technological innovation.

Iron and steel constructions represent a symbol of industrial culture, also to be considered in the framework of the European dimension, that found in the European Coal \& Steel Community (ECSC) its first continental community platform (Miller et al., 2010), but in Italy it has often been considered as an expensive alternative to reinforced concrete structures, especially in the contexts which has always preferred traditional techniques instead of the introduction of possible innovations in the building sector.

However iron and steel constructions can boast a tradition that even in the peninsula is long at least two centuries, well in advance of first experimentations of the reinforced concrete. Therefore the $19^{\text {th }}$ century was not only the "century of machines" (Eco, 2015) or "the century of engineers", but also "the Age of Iron and Cast Iron" (Koyré, 1961), to reaffirm the bond between "industrialism" of beginning, after the Italian unification, and ferrous materials, a combination which resulted also in major infrastructures and in many buildings with iron structure, and which earned a large approval in some historical periods.

In the $19^{\text {th }}$ century it also began a process of higher training for specialized technicians in the iron construction and later there was also the production start-up of an industrial system that was able to guarantee large quantities of metal components (Jodice, 1985). Therefore the $19^{\text {th }}$ century set the stage for a possible and widespread diffusion of iron and steel structures in the building sector, also due to the gradually increasing of the national steel production during the early decades of the "short century".

However, these potential conditions didn't have success, indeed since the first years of the $20^{\text {th }}$ century complex factors slowed down the experimentation and the use of metal components in the construction industry: the Great War and social-economic upheaval; the autarkic period, with an imposed limitation of the consumption of iron and steel products, which were mainly intended to heavy industry and arms industry in particular; the spread of the reinforced concrete in the building sector. Some significant experiences - such as the experimental buildings carried out in the Triennale in Milan of thirties (Chiodi, 1932) and Anfimi's competitions for the promotion of steel structures (D'Orazio, 2008) - took often the character of occasional opportunities but could not produce effective impacts into the construction industry.

The economic upturn in the fifties and sixties, set up a profound transformation of the country. In this new economic and social scenario, emerging needs, which had been deliberately put aside in the first post-war period, provided valid opportunities for the effective and consistent testing of steel structures. In particular, some architectural themes arose as a consequences brought about by the economic recovery: school buildings, which bound to policies of overcoming illiteracy; the industrial buildings and those for tertiary sectors, functional to the industrialism process that needed a strong demand of factories and management offices for emerging companies.

In this period the steel construction in Italy took on an original character: experimental architectures combined the innovative solutions offered by the steel technology and a new interpretation of tradition, matching industrial culture with craft 
background and identity of cities. Despite steel construction seemed to have a "marginal role" if compared to the large application of reinforced concrete, it was often used by designers to enhance an architectural and technological singularity, defining buildings that still nowadays are key players in their urban contexts, because of their relevant location, economic value and architectural quality.

Investigations about Italian steel architectures has only partially been carried out, in a deeply fragmented way: it is possible to reference the studies carried out by researchers at the Faculty of Architecture at Sapienza University of Rome, that have retraced the history of Italian iron architecture until the First World War (Jodice 1985); studies of the Polytechnic University of Marche, that has investigated the topic of metal construction, proposing contributions on 1930's experiences (D'Orazio 2008); some researches has been conducted by the University of Cassino, producing surveys spanning a larger period, including 19th and 20th century (Zordan 2006). This is the reason why a group of research of the University of L'Aquila has focused the research on this heritage, analysing specific typologies made in iron and steel, such as housing, bridges, factories, schools, offices, department stores, and also large-span roofs and high-rise buildings; this research group has also conducted studies about public and private clients that encouraged the use of metal components for structures and considered not only the importance of these building in the time of their construction, but their current relevance.

From this point of view it is necessary to underline the possible integration of iron and steel construction studies with themes of the architectural heritage, within the framework of building restoration criteria. Furthermore the heritage of steel architectures has not yet found a right appreciation as has happened in other foreign countries: in Great Britain an ambitious program of safeguard has been applied in the historical iron production area of Ironbridge-Coalbrookdale ('Coalbrookdale Museum of Iron - The Ironbridge Gorge Museums', n.d.); in Germany, mining industries of Ruhr region have been redeveloped activating an unexpected and thriving tourism economy (Ruhr Museum, n.d.); in the US, steel factories of Pittsburgh, also known as "steel city", have been converted into a cultural centre (Montipò, 2017).

\section{THE PROPOSAL OF A HBIM METHOD FOR STEEL ARCHITECTURAL HERITAGE}

The foundation of a valorisation project of Italian iron and steel architectures, is represented by their recognition as a cultural heritage and, according to the conventions established by Unesco, also by the identification of their tangible and intangible values ('UNESCO', 2018; Vecco, 2010).

Therefore it is necessary to apply strategies and tools that could benefit the valorisation project, articulated not only in a process of history and building importance divulgation, spread to wider and wider communities as it is recommended by ICOMOS (ICOMOS, 2015), but also in a dynamic and adaptive conservation, able to identify compatible transformative actions. Most of the architectures sustained by steel structure in Italy were built in the second half of 1900s and their relatively close date of construction did not induce local administrations to guarantee an appropriate protection.

Furthermore contemporary transformations have sometimes deeply altered original features of steel buildings, as a consequence of the application of conventional design and technical solutions, due to bad practices that are not inspired by preservation principles, but only by economic advantage or the achievement of energy standards. These aspects describe the "weakness" of this heritage, that risks being lost or deeply altered.

An useful tool for its necessary enhancement may be represented by BIM and its potentialities. Some experimental studies have already focused on steel architectures as one of Cagliari's university pavilion, designed by Enrico Mandolesi, examined by a research group of Milan and Cagliari universities through a BIM methodology proposing a workflow for the analysis and renovation of this specific architecture (Di Giuda et al, 2017b); other studies concerned the heritage of Rai buildings, composed by some steel architectures as Rome and Turin headquarters (Di Giuda et al., 2017a). These researches have been particularly developed for the control and management of buildings and they could be considered as preparatory studies for possible energy and structural retrofit operations. A fundamental issue is lacking in these models: the importance of historical and design nature of these architectures, that could be included by the ontology of BIM asbuilt (Volk et al., 2014), in other words, a smart model.

Indeed BIM could be suitable not only to depict the current consistency of old buildings, but also a system of information addressed to restore the historical origin, the re-enactment of evolutionary phases and also the collection of material and technical data used at the time of construction. At the same time, this tool could be interactive, so as to guarantee the collaboration of different players, each one with his own expertise. The limit shown by these Italian studies, moreover few in number, is the application of a conventional BIM approach, the same developed for new constructions, whereas it could have been necessary to merge this approach with methodologies studied for historical heritage, recently known as HBIM (Murphy et al., 2009; Oreni et al., 2014; Volk et al., 2014; Dore and Murphy, 2015; Brusaporci et al., 2018; López et al., 2018; Pocobelli et al., 2018; Salvador García et al., 2018). Murphy affirms that HBIM is "a novel prototype library of parametric objects, based on historic architectural data and a system of cross platform programmes for mapping parametric objects onto point cloud and image survey data" (Murphy et al., 2009), whereas other researchers state that it is "a multidisciplinary system consisting in the construction of smart objects (parameterized on the basis of architectural rules and treatises) on the data deriving from the building survey" (Brusaporci et al., 2018).

Researches about HBIM, grown very fast in the last decade, still reveal some critical points, mainly represented by the difficult modelling of historical features of building components, too complex in a traditional BIM workflow. Other problems are "the unavailability of historical parametric object libraries and the lack of tools for managing complex, irregular, and uncertain shapes that are obtained from point clouds" (López et al., 2018). This is also true for the modern heritage, considering that few researches have tried to focus on the HBIM application to it, as some studies about modern Brazilian and Indian architectures (Balzani et al., 2016; Balzani et al., 2017); therefore the potentialities of a HBIM approach applied to steel architectures of $20^{\text {th }}$ century are still unexplored and it is necessary to develop a particular working procedure.

This process of definition and check, stems by the specific nature of metal construction, characterised by original features, compared to those of traditional building techniques or reinforced concrete. Indeed the introduction of iron represented a deep revolution for building techniques (Nardi, 2001), proposing a significant prefabrication of building components and new systems of dry assembly. However prefabrication didn't always match with standardisation or, in particular, normalisation; leading to the availability in the market of different metal components, according to decades and countries, 
an aspect that partially survives still nowadays, considering that most of steel standard profiles used in Europe are different from those applied in the other continents. Furthermore this condition is more evident in Italy, where the building market was not independent for a long time, especially in the case of iron and steel construction, often resorting to the importation of components and techniques particularly developed in France and England. The result was the introduction in different periods, over two centuries, of different steel profiles, sections and materials. Therefore the study of architectures sustained by steel structure of $19^{\text {th }}$ and $20^{\text {th }}$ century, would require the availability of components libraries, considerably wide and hardly ever attributable to default BIM families.

The present contribution presents a HBIM methodology that tries to improve, through the creation of specific libraries and database of material components, the process of semantic classification and parametric operability of steel building elements used both for structures and envelopes. The proposed procedure is organised in three parts (Figure 1): the first one devoted to a cognitive phase, the second one characterised by the creation of components libraries and the third one addressed to the final BIM modelling.

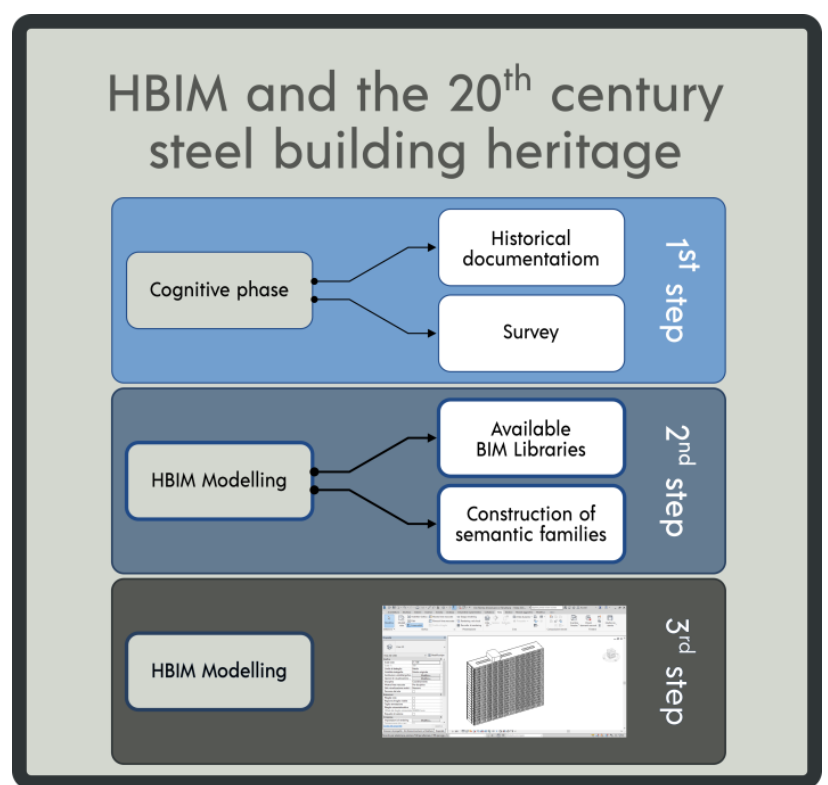

Figure 1: Framework of the BIM process for the architectural heritage made in steel.

\section{FIRST STEP: COGNITIVE PHASE}

The first step consists in the process of knowing, essential for a detailed re-enactment of history of architectures sustained by steel structure. This process may be organised in more stages (Figure 2), from which it is possible to obtain different operational addresses. In the first stage it is necessary to check the availability of original documentation about the buildings, through investigations about primary and secondary sources, archival and bibliographic material (Figure 3). According to the quality and quantity of these documents, different levels of knowledge (LoK) could be defined, ranging from complete to limited or, at worst, insufficient. The levels are referred to technological solutions applied between structure and envelope, to the transformation phases regarding the analysed building and to the characterisation of building materials. In the case of some Italian architectures, as the heritage connected to important national companies like Olivetti, Eni and Rai, the availability of complete archival sources allows the achievement of a LoK with a high score, whereas in the case of other architectures, sometimes less well-known, like the steel sport facilities built in Italy between $50 \mathrm{~s}$ and $60 \mathrm{~s}$, an incomplete documentation does not allow the same result.

For the evaluation of LoK levels contribute not only the elements connected to the morphological configuration of the building, but also to material elements, that may be firstly studied through a specific research on reviews and manuals of the time of their production (Di Lorenzo et al., 2016). A fundamental aspect is represented by the collection of historical tables showing dimensions and details, technical reports and advertisements of producers containing technological information, all documents that may be useful to correctly understand geometry and shapes of steel components, a particular that is evident for concealed structures, for which it is not always possible to resort to a direct survey (Figure 4). Another study that may enrich the knowledge about the analysed architecture is the comparison with other buildings designed at that time, investigating also between those designed and built by the same author and construction company, understanding the development of specific architectural configuration through the use of steel construction components.

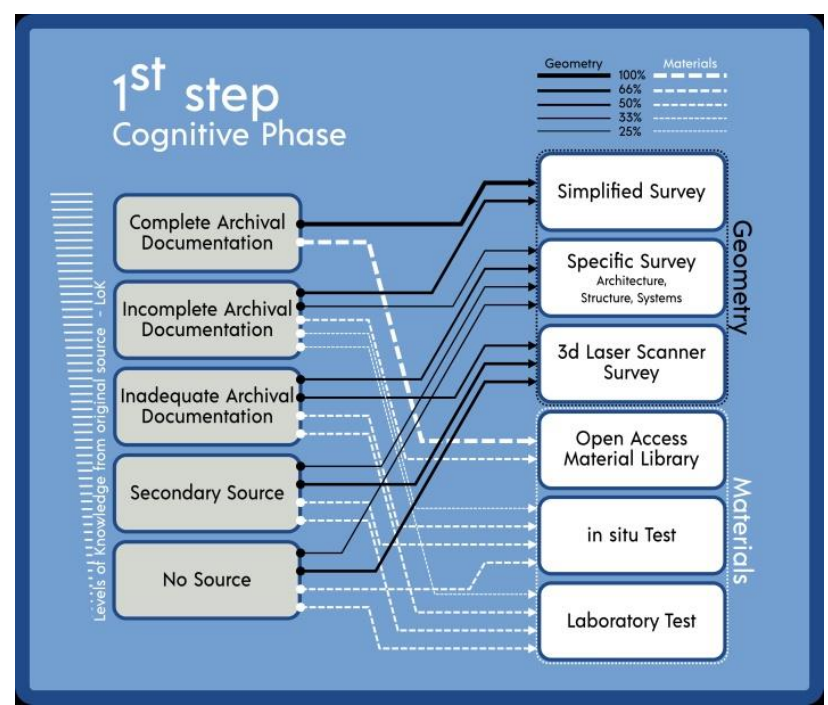

Figure 2: The $1^{\text {st }}$ step with the definition of the LoK (Level of Knowledge) and the following choice of the suitable survey.

If this documentation is not available, specific on-site and laboratory investigations must be carried out, in order to determine the characteristics of metal components and materials that make up the various stratigraphy of the envelope; in order to make it possible it's necessary to arrange special thermoflowmeter surveys, functional to the definition of the actual thermal resistances of walls and floors (Lucchi, 2013).

These collected data could flow into one or more open access databases, which could permit the realisation of libraries useful for the semantic process of definition of different and detailed families forming the BIM models. Therefore the availability of these libraries could represent the starting point for activating HBIM-type procedures for the study of Italian architectures made in steel, a consistent premise for carrying out structural analysis and Building Performance Simulation examinations (BPS) on individual components and complete BIM models.

The first phase is followed by the survey of case-studies buildings, which can be organized according to the determined LoK: if the Lok is high, the survey can be done with a traditional instrumentation, to check if the available documents are responding to the current situation of the building. This could be the case, for example, of the ENI's office building at 


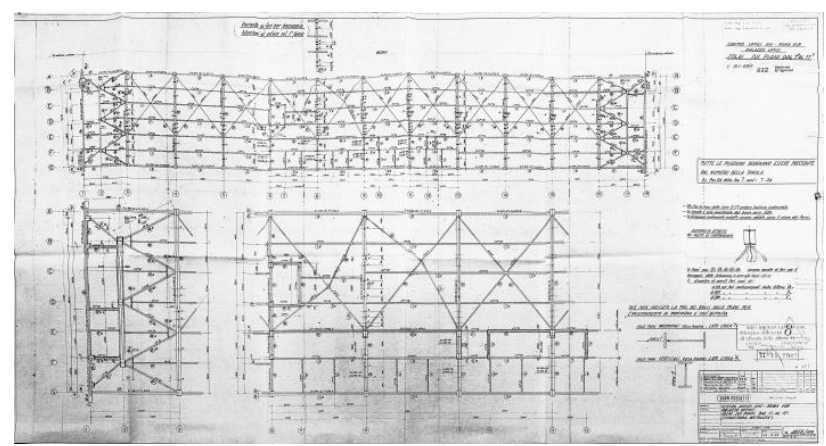

Figure 3: a carpentry plan of the ENI Office Building in Rome (courtesy of ENI's Archive)

\section{facciate continue FEAL}

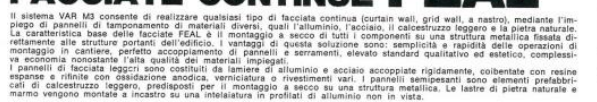

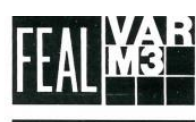
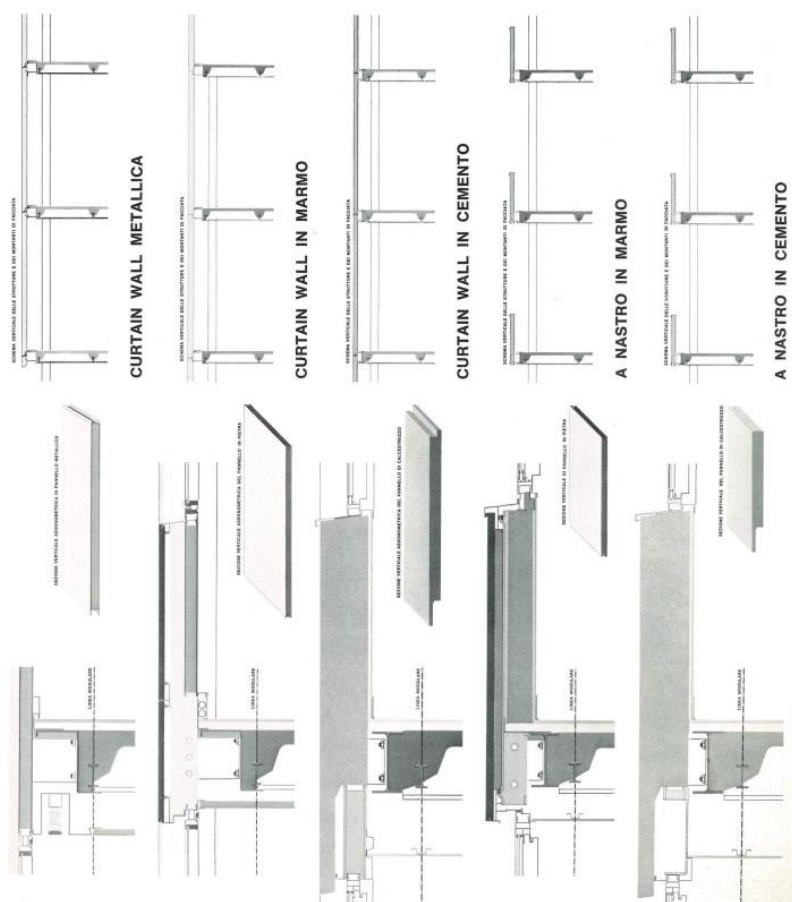

Figure 4: an advertising of a prefabricated envelope produced by Feal in the seventies.

EUR in Rome, thanks to the rich archival documentation and the good conservation. If the LoK is low, it's necessary to achieve a survey that may also include the use of Laser scanner or photogrammetric surveys, according to the complexity of structures and technological solutions. For example, this option could be useful for the study of some industrial archaeology made in steel, such as the twentieth century "Officine Galileo" in Florence, that have a low LoK. If an examined building shows an inadequate state of conservation, in spite of its high LoK, a survey will be provided using a laser scanner or photogrammetry, in order to allow a subsequent photographic post-processing for the mapping of the decay and the definition of subsequent refurbishment interventions, as shown by some studies of different research groups (Balzani et al., 2017). For example, this approach could concern the examination of some steel bridges still in use, such as the bridge called "ponte all'Indiana" - built in the seventies in Florence - for which it could be possible to organise a laser scanner survey similar to the survey concerning the Forth Bridges in Scotland (Iftikhar et al., 2017).

\section{SECOND STEP: BUILDING COMPONENTS CENSUS}

After the completion of the cognitive phase, it is necessary to start the definition of the technological components that will be used for the model construction (Figure 5).

The "building components census" could be generally divided in two reference areas that propose a summary of the whole framework compared to the complex construction totality: in the "steel structure" area could be included components as columns, pillars, beams and sustaining parts of the slabs, elements which determine the morphology of the steel frame and that could be potentially suitable for structural analysis; whereas in the "envelope" area are involved walls, masonry, doors and windows or, more frequently, curtain walls, that complete the configuration of the building and usually define its figurative and architectural quality.

With a view to obtain a model that could be appropriate to be used both for digital archives and for multidisciplinary analysis, it is necessary to consider the Level Of Development (LOD) of the components that cannot be less than 400 , therefore, the official standard set by advanced studies in this field must be taken into account.

Taking the steel structure as an example and according to the studies of the American office AEC Engineering (Bedrick, 2013) and AIA, the Ameican Institute of Architects (BIMForum, 2018), the level LOD 400 corresponds to the modelling of construction elements with the complete detail of joints and connections, which can give information about the assembly of metal carpentry.

About the topic of the steel structure, it is possible to find three different cases, to which correspond two distinct operational addresses. If in the existing building are used structural components that are still produced nowadays, according to the features established by international official tables (ITII, 2004), a traditional BIM workflow can be followed, indeed these components are easily available in the system families of authoring softwares or in the libraries supplied by producers and companies. A paradigmatic example of this situation is represented by COIN department store placed in Piazza San Giovanni in Rome, that, despite it was built more than forty years ago, it uses, both for columns and beams, HE profiles connected by flanges clamped through high strength bolts, all elements which are used still nowadays in the constructional praxis (Romaro, 1977).

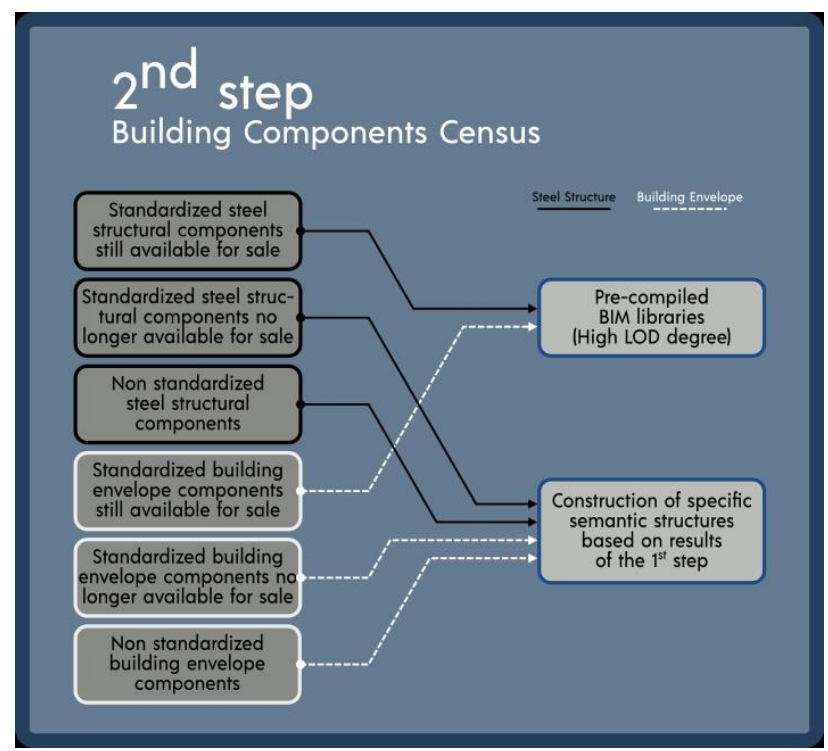

Figure 5: the second step framework, consisting in a building components census. 
On the contrary, if the existing building is made of structural components that are no longer available in the market, or, construction elements specifically assembled to follow particular structural needs, new loadable families must be created considering the information taken in the first step, following a traditional HBIM workflow. This kind of procedure is rather common for steel buildings of the first half of $20^{\text {th }}$ century and of $50 \mathrm{~s}-60 \mathrm{~s}$, caused by the lack of international compliance at the time, and by the need of industrial importation of steel profiles: La Rinascente department store located in Piazza Duomo in Milan, one of the first steel buildings of the Italian post-war reconstruction, is built of Grey de Differdange steel profiles, produced in the steel mills of Luxemburg (Brustio, 1950); whereas First and Second Office Buildings of Eni Group in Metanopoli, are built of steel profiles specifically welded in order to follow the complex geometry of architectures (Studio BR, 1976).

Furthermore for steel structures, connections take on great importance and taking into account the reference level of LOD 400, they should be highly detailed (Figures 6-7). Some critical points come to light regarding steel connections: join systems still used in the first half of $20^{\text {th }}$ century, as hot rivets, are absent in the most of softwares, and exposed connections, that decisively participate to the architectural configuration of the building present sometimes a level of geometrical complexity that cannot be easily reproduced with tools offered by BIM softwares (Bock and Linner, 2015).

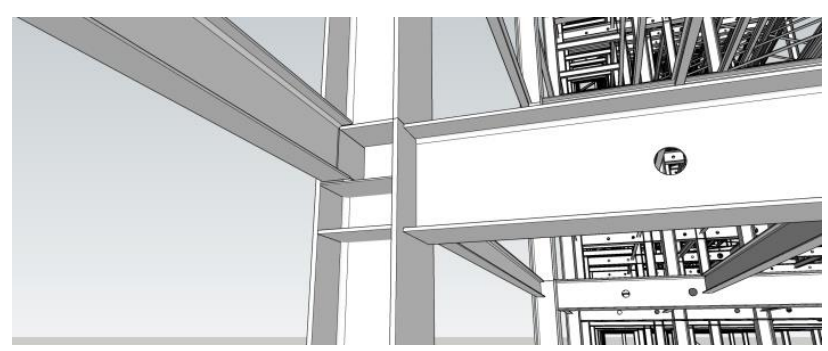

Figure 6: a steel node of the ENI Office Building in Rome.

\begin{tabular}{|c|c|c|c|}
\hline \multicolumn{4}{|c|}{ Proprietà del tipo } \\
\hline Famiglia: & $v$ & Carica... & \\
\hline & $v$ & Duplica... & \\
\hline Tipo: & & Rinomina... & \\
\hline \multicolumn{4}{|l|}{ Parametri tipo } \\
\hline Parametro & \multicolumn{2}{|l|}{ Valore } & $=\wedge$ \\
\hline \multicolumn{2}{|l|}{ Dati identità } & $\hat{\imath}$ & \\
\hline Immagine tipo & \multicolumn{2}{|c|}{ Archivio Eni_colonna perimetrale } & \\
\hline Nota chiave & \multicolumn{3}{|l|}{ Piatto nodo C-T 6-42 } \\
\hline Modello & \multicolumn{3}{|c|}{ Piatto di continuità nodo colonna tr } \\
\hline Produttore & \multicolumn{3}{|c|}{ Officine Bossi di Milano - 1961} \\
\hline Commenti sul tipo & \multicolumn{3}{|l|}{ Piatto di dimensioni } \\
\hline URL & \multirow{2}{*}{\multicolumn{3}{|c|}{ https://www.eni.com/enipedia/it }} \\
\hline Descrizione & & & \\
\hline Parametri IFC & & $\hat{\imath}$ & \\
\hline IfcTert & \multicolumn{3}{|c|}{ profile $=\mathrm{H}-350 \times 350 \times 12 \times 23 \times 27 \mid$ materi } \\
\hline IfcDescription & \multicolumn{3}{|l|}{ Joint plate - I steel } \\
\hline Ifclabel & \multicolumn{3}{|l|}{ STEEL_COLUMN } \\
\hline NameOverride & \multicolumn{3}{|l|}{ Plate 2781 } \\
\hline If cldentifier & \multicolumn{3}{|l|}{ Colonna ENI 1-5 ridotta } \\
\hline & & & $\checkmark$ \\
\hline$<<$ Anteprima & Annulla & Applica & \\
\hline
\end{tabular}

Figure 7: labels of the steel join shown in the figure 6, concerning several aspects, both structural and historical.
For this reason it is necessary to establish, before the creation of the model, a library of connections developing new loadable families, if they are used in series in the structure. From the ongoing modelling of analysed buildings, the group of research aims to develop a special library containing the most common steel connections, in particular of the second half of $20^{\text {th }}$ century, which could be spread with an open-source model. The second reference area concerns the envelope and it can be treated in the same way described for steel structural elements, even if the variety of curtain wall types and the great range of figurative solutions, entail a more varied scenario compared with the previous. Moreover the envelope corresponds sometimes with the expressive characterisation of the building and it could be submitted to energetic analysis that inevitably influence the indoor comfort and resulting criteria for the restoration project (Lapinskiene and Martinaitis, 2013).

In contrast to American and North European architectural panorama, where it is possible to find envelope components serially used on a large set of buildings, in Italian architecture curtain wall usually represents a singularity (Poretti, 2006), specifically designed to follow the features of an urban context or shaped to express the language of a particular designer. EssoSgi building located in Eur district in Rome or Rai skyscraper in Turin, show a well-structured envelope enriched by exposed steel profiles, metal plates, modern mouldings... elements that give a remarkable effect, but require the development of particular loadable families in the BIM modelling.

A critical point can be represented by the lack of technical documentation regarding the envelope, indeed this kind of information is sometimes absent in designers archives, because it is held by curtain wall technicians and companies, like Feal, Curtisa, Alsco Malugani, firms that are no longer in service. In order to solve this problem, it is necessary to search other realisations of the involved company, studying in deep materials and details described in reviews and manuals of the analysed time, collecting useful information that lead to the construction of the components with a LOD that is comparable to the other elements of the model. Physical and mechanical information about the envelope pieces can be taken by archival and bibliographic sources, but in order to give more reliability to future BPS analysis, it is sometimes advantageous to verify data and values through material and thermal testing using specific instruments on the real components.

Another important topic is the quantity of dangerous materials, no longer approved by the law, that should be removed from building components and substituted (Kensek, 2014). In the steel architectures of $20^{\text {th }}$ century, is rather common to find between envelopes and finishes, asbestos panels and protection coverings, especially used for fire and thermal protection, that cannot be employed anymore in the building industry because of the damaging consequences on human health. In the study of technological components, the toxic character or the inadequacy to the law, can be easily reported through the introduction of specific labels, in order to favour the materials management in the restoration project.

\section{THIRD STEP: MODELLING}

The availability of detailed technological components, conveniently developed in the second step of the workflow, allow the construction of the model, that is the final result of the whole procedure (Figure 8).

Operational praxis of BIM generally foresees the management of the model through a threefold organisation divided into the modules architecture - structure - systems, that reflect the commercial formulation of BIM Authoring softwares (Odorizzi, 


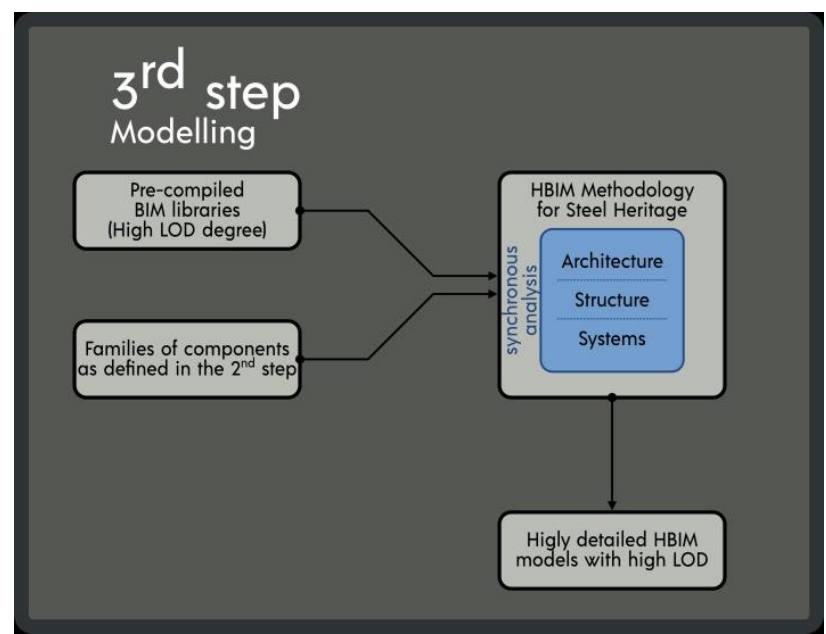

Figure 8: the third step framework, consisting in the modelling.

2017), a separation that permit to different technicians working on the building to develop multiple analysis and change it according to the results. This organisation does not seem to be particularly appropriate for most of steel architectures of $20^{\text {th }}$ century, because there is not a clear limit between the modules, but a mixture, that derives from the integration design between form and function, one the most meaningful topic of this architectural heritage.

It's not uncommon to find buildings for which the structure plays the key-role of the whole architectural configuration, presenting a particular shape of steel profiles and connections, and solving in the same way static and formal needs. Buildings like La Rinascente department store and headquarters of Telecom, both placed in Corso d'Italia in Rome, show an exposed steel structure and envelope panels specifically shaped according to the systems canalizations, therefore, these examples express an horizontal relationship between the modules architecture - structure - systems, because each one takes part of the others. This kind of buildings lead to leave the traditional approach of detached modelling, for which, for instance, it is possible to avoid in the architectural module the insertion of beams, sustain parts of the slab or systems devices; sometimes it is necessary to completely model the steel structure, integrating it into the architectural module, and at least to shape the geometry of canalizations if they fully participate to the architectural configuration of the building.

An open question about HBIM is also represented by the parametric level of the model considering that it regards an existing building (Paris and Wahbeh, 2016): sometimes it presents a lower quality compared to BIM addressed to new constructions, because of the difficult drawing translation of particular historical components and the geometrical-technical singularity of certain elements. In the case of steel architectural heritage of $20^{\text {th }}$ century, this debate acquires less importance because the most of the technological components, despite their complex shape or arrangement, are often designed to be reproduced in series. For instance in the Third Office Building of Eni Group in Metanopoli, cladding panels display a distinctive shape composed by volutes and mouldings that interpret the historical architecture, but they are used in series and can be developed with a high parametric quality.

Foreseeing the use of the model for future maintenance programs or restoration interventions, it is also important that all the components are managed through labels and marks previously defined according to a precise database classification (Di Giuda et al., 2017a). Indeed an orderly categorisation of the modelling objects, may lead to easily obtain tables and quantities.

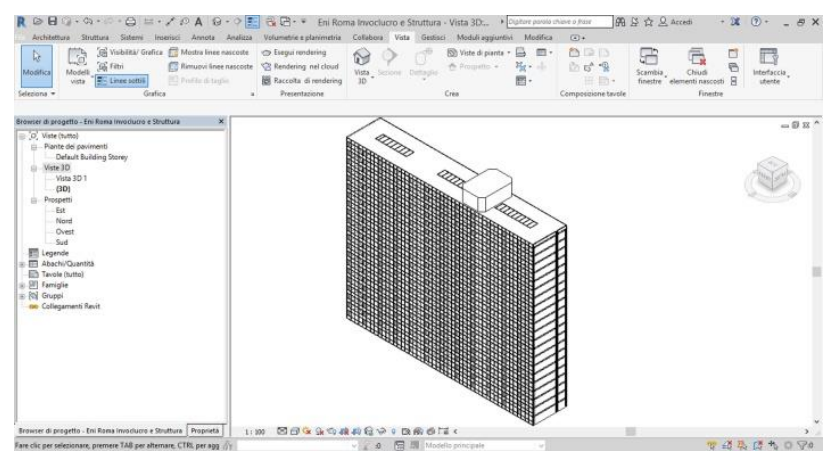

Figure 9: the BIM model of the ENI Office Building in Rome

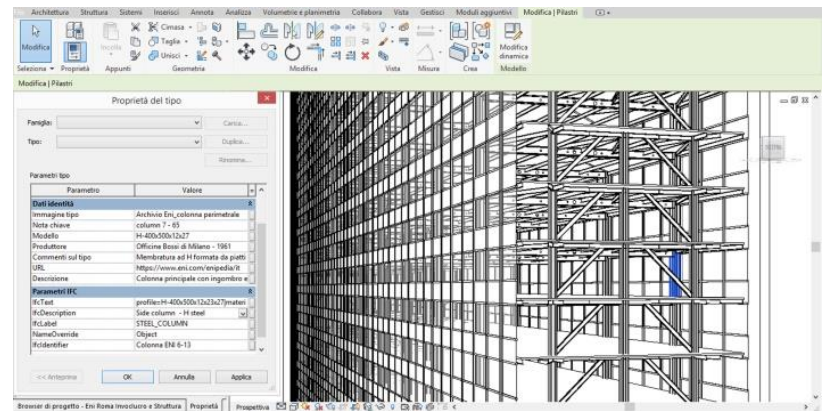

Figure 10: a database of a column of the ENI building in Rome.

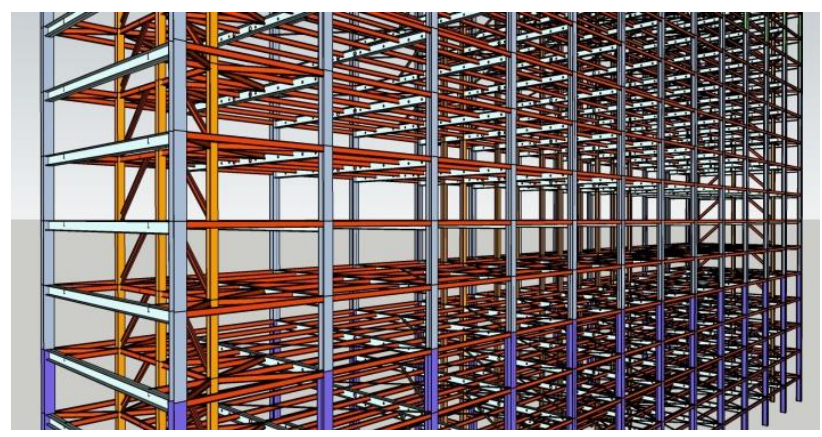

Figure 11: different structural profiles used in the construction of the ENI Office Building.

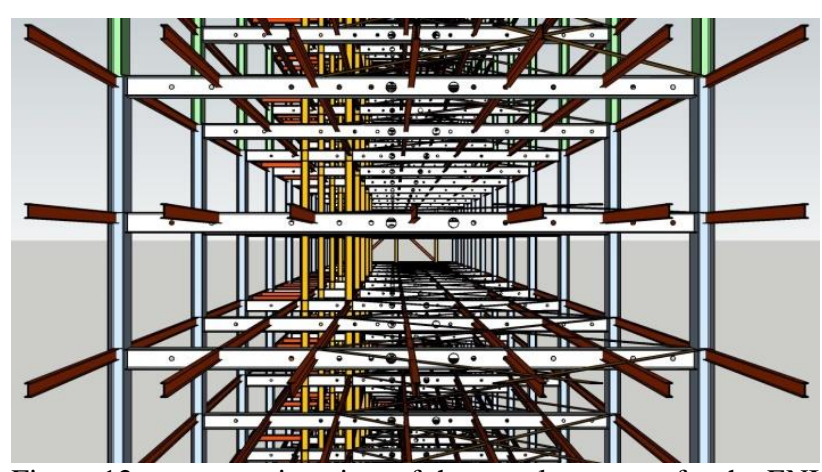

Figure 12: a perspective view of the steeel structure for the ENI Office Building in Rome.

Another important data that should be expressed by the model is the state of deterioration of surfaces and materials, in order to manage future conservation interventions. In addition to the information deduced from the first two steps, it is possible to attach highly detailed ortophotographs to the model surfaces, highlighting the areas that present functional problems and labelling their causes. The mapping of the deterioration state aims to achieve an automatic evaluation of the building condition through the concept of Diagnosis Aided Historic Building Information Modeling and Management (DA- 
HBIMM), which automates "the diagnosis process through reasoning algorithms of decay and settlement symptoms" (Bruno, 2018), thanks to an inferential logic connected to images and building data.

Models of Eni Group Headquartes located in Eur district in Rome (Figures 9-12) and "Attrezzaggio" factory of Olivetti placed in Ivrea, near Turin, (Figures 13-14) are a clear demonstration of the possibility to develop a model rich of information suitable for scientific divulgation, maintenance programs or conservation project control. Both have been studied in deep through original documentation taken in public and private archives and the reliability of the executive drawings has been verified through examinations on site that have excluded the need of a direct survey. Bibliographic and archival sources were thorough enough to develop the technological components, sometimes introduced with new loadable families, because of the presence of steel elements no longer available in the market.

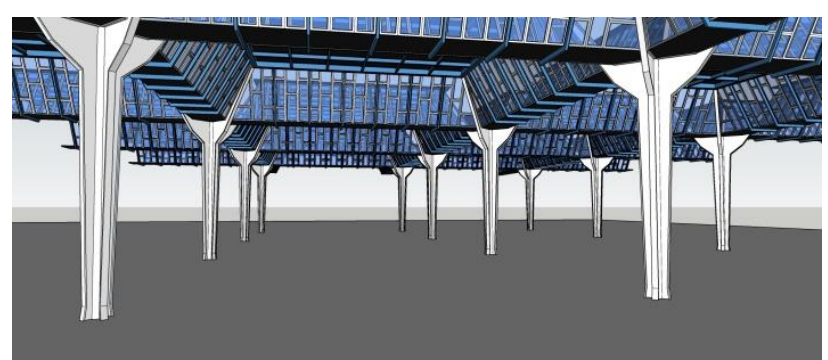

Figure 13: a perspective view of the Olivetti's Officina $H$ in Ivrea.

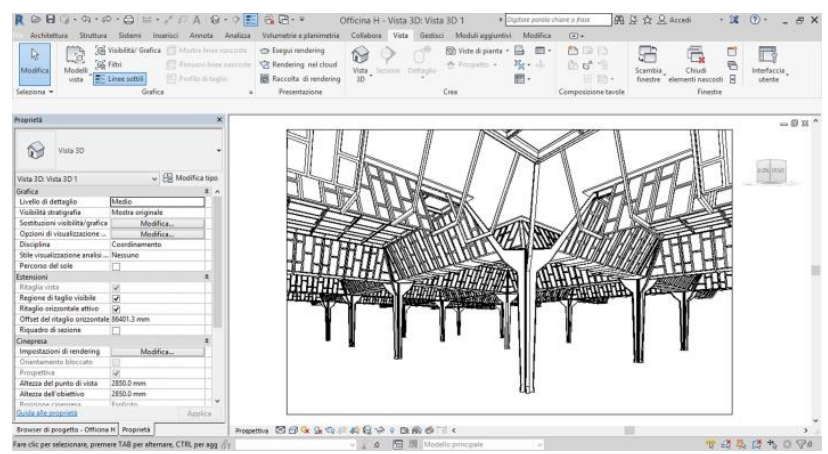

Figure 14: the BIM model of the Officina $\mathrm{H}$.

\section{CONCLUSION}

The suggested methodology proposes, with two different operational registers, a tool useful to define guidelines for the preservation and valorisation of the $20^{\text {th }}$ century heritage made in steel.

Indeed the definition of cognitive frameworks and their database structure produce a HBIM modeling available to define a Virtual Heritage that could be useful for the realisation of an iron and steel construction observatory and for the definition of an augmented reality project.

Through the organization of the cognitive frameworks into a data warehouse models, the HBIM modeling can be an operational platform for multifactorial analysis and a multicriteria evaluation, useful to address complex and different design options which range from a routine maintenance to a complete restoration. This multicriteria evaluation aims to reach not the optimization of building performances, but the optimal that should be suitable for the historic and architectural features of buildings.
From this point of view, the HBIM interests not only geometrical parameters, able to define the characteristics of the physiognomy of buildings, but also decision-making criteria able to address any possible transformation of their physiology, with the aim of guaranteeing a continue conservative action.

\section{ACKNOWLEDGEMENTS}

The authors would like to acknowledge the Archives of Eni, Olivetti and Rai, for providing documents sources.

\section{REFERENCES}

Balzani, M., Maietti, F., Medici, M., 2016. La rappresentazione BIM per la documentazione e l'analisi storico-critica del patrimonio modernista. In: DisegnareCon, Vol. 9(16), pp. 8.18.7.

Balzani, M., Maietti, F., Mugayar Kühl, B., 2017. Point cloud analysis for conservation and enhancement of modernist architecture. In: ISPRS - International Archives of the Photogrammetry, Remote Sensing and Spatial Information Sciences, Vol. XLII-2/W3, pp. 71-77.

Bedrick, J., 2013. A Level of Development Specification for BIM Processes. AECbytes.

BIMForum, 2018. Level of Development Specification Guide 2018. BIMForum.

Bock, T. and Linner, T., 2015. Robotic industrialization: automation and robotic technologies for customized component, module, and building prefabrication. Cambridge University press.

Bruno, S., 2018. Modellazione informativa del patrimonio storico verso l'automazzazione della diagnosi (DA-HBIMM). Edilizia Circolare, Cagliari 12-14 settembre, pp. 270-271.

Brusaporci, S., Maiezza, P., Tata, A., 2018. A framework for architectural heritage HBIM semantization and development. In: ISPRS - International Archives of the Photogrammetry, Remote Sensing and Spatial Information Sciences, Vol. XLII-2, pp. 179-184. https://doi.org/10.5194/isprs-archives-xlii-2-1792018

Brustio, G., 1950. Relazione del 26 aprile 1950 sulla ricostruzione del nuovo grande magazzino La Rinascente, Milano Piazza Duomo. La Rinascente.

Chiodi, C., 1932. Il Concorso G. E. Falck, supplemento al numero supplemento al n. 7 - 8 di Rassegna di Architettura. In: Rassegna di Architettura, Vol. IV(7-8), pp. 7-40.

Coalbrookdale Museum of Iron - The Ironbridge Gorge Museums [WWW Document], n.d. . Ironbridge. URL https://www.ironbridge.org.uk/explore/coalbrookdale-museumof-iron/ (accessed 12.18.18).

Di Giuda, G.M., Maltese, S., Re Cecconi, F., Villa, V., 2017a. Il BIM per la gestione dei patrimoni immobiliari: Linee guida, livelli di dettaglio informativo grafico (LOD) e alfanumerico (LOI). Hoepli.

Di Giuda, G.M., Quaquero, E., Villa, V. et al., 2017b. Workflow BIM per la gestione e la valorizzazione dell'architettura moderna. Il padiglione Mandolesi dell'Università degli Studi di Cagliari In: Bernardini, G., Di Giuseppe, E., ColloquiATe 2017. Demolition or reconstruction? Atti del Convegno (Ancona, 28 settembre 2017). Edicom Edizioni 
Di Lorenzo, G., Landolfo, R., Avallone A., 2016. Le leghe ferrose per impiego strutturale dal XIX secolo ai nostri giorni: evoluzione dei processi e delle proprietà meccaniche. In D'Agostino, S., History of Engineering Storia dell'Ingegneria Proceedings of the 2nd International Conference Atti del $6^{\circ}$ Convegno Nazionale Naples, 2016 April 22nd - $23^{\text {rd }}$, Vol. 1, Cuzzolin, pp. 235-244.

D'Orazio, M., 2008. Contributi alla storia della costruzione metallica: progetti e realizzazioni degli anni '30 per l'edilizia abitativa. Alinea Editrice.

Dore, C., Murphy, M., 2015. Historic Building Information Modeling (HBIM). In: Brusaporci, S., Handbook of Research on Emerging Digital Tools for Architectural Surveying, Modeling, and Representation. IGI Globa, pp. 239-279.

Eco, U., 2015. L'Ottocento. Il secolo delle macchine vol.: 1-2 Storia, filosofia, scienze meccaniche - Letteratura e teatro, arti visive, musica. Encyclomedia Publishers.

ITII, International Technical Information Institute, 2004. Handbook of comparative world steel standards. John E. Bringas Editor.

Kensek, M.K., 2014. Building Information Modeling - BIM in current and future practice. Wiley.

Koyré, A., 2014. Dal mondo del pressappoco all'universo della precisione. Giulio Einaudi Editore.

Jodice, R., 1985. L'architettura del ferro: l'Italia (1796-1914). Bulzoni editore.

Iftikhar, U., Jackson, B., Vialva, T., Petch, M., Clarke, C., 2017. 3D scanning and education using Scotland's Forth bridges - 3D Printing Industry [WWW Document]. 3D Printing Industry. URL https://3dprintingindustry.com/news/3d-scanningeducation-using-scotlands-forth-bridges-101976/ (accessed 12.20.18)

ICOMOS. 2015. ICOMOS Ename Charter for the interpretation of cultural heritages sites.

Lapinskiene, V., and Martinaitis, V., 2013. The Framework of an Optimization Model for Building Envelope. Procedia Engineering, Vol. 57, pp. 670-677.

López, F., Lerones, P., Llamas, J., Gómez-García-Bermejo, J., Zalama, E., 2018. A Review of Heritage Building Information Modeling (H-BIM). In: Multimodal Technologies and Interaction, Vol, 2(21), pp. 1-29.

Lucchi, E., 2013. Il comportamento termofisico dell'architettura preindustriale. In Pracchi, V., Lucchi, E. (eds), Efficienza energetica e patrimonio costruito. La sfida del miglioramento delle prestazioni nell'edilizia storica, Maggioli Editore, pp. 85118.

Miller, F.P., Vandome, A.F., McBrewster, J., 2010. European Coal and Steel Community. VDM Publishing.

Montipò, C., 2017. Stati Uniti, così si sono riciclate le fabbriche/2. Il caso di Pittsburgh | Giornale dell'Architettura | Periodico in edizione multimediale [WWW Document]. URL http://ilgiornaledellarchitettura.com/web/2017/12/18/stati-uniticosi-si-sono-riciclate-le-fabbriche2-il-caso-di-pittsburgh/ (accessed 12.18.18).

Murphy, M., McGovern, E., Pavia, S., 2009. Historic building information modelling (HBIM). In: Structural Survey. Vol. 27, pp. 311-327.
Nardi, G., 2001. Tecnologie dell'architettura Teorie e Storia. Libreria CLUP.

Odorizzi, P., 2017. L'approccio digitale nei progetti e nelle costruzioni. Costruzioni Metalliche, Vol. 64 (6), pp. 9-12.

Oreni, D., Brumana, R., Georgopoulos, A., Cuca, B., 2014. HBIM Library Objects for Conservation and Management of Built Heritage. In: International Journal of Heritage in the Digital Era, Vol. 3, pp. 321-334.

Paris, L., Wahbeh, W., 2016. Survey and representation of the parametric geometries in HBIM. In: Disegnarecon, Vol. 9(16), pp. 12.1-12.9.

Pocobelli, D.P., Boehm, J., Bryan, P., Still, J., Grau-Bové, J., 2018. BIM for heritage science: a review. In: Heritage Science, Vol. 6 (30), pp. 1-15.

Poretti S. (2006) Curtain Wall all'italiana. In: Bardelli, P.G., Cottone, A., Nuti, F., Poretti, S., La costruzione dell'architettura, temi e opere del dopoguerra italiano. Gangemi Editore, Roma, pp 39-48.

Roisecco, G., 1972. L'Inghilterra (1688-1914).

Romaro, G., 1977. Le tecniche di costruzione nella fase progettuale dei telai multipiano in travi di acciaio. Acciaio, Vol. 18(3), pp. 110-116.

Salvador García, E., García, E.S., García-Valldecabres, J., Blasco, M.J.V., 2018. The use of HBIM models as a tool for dissemination and public use management of historical architecture: A review. In: Int. J. Sustainable Dev. Plann. Vol. 13, 96-107. https://doi.org/10.2495/sdp-v13-n1-96-107

Ruhr Museum, n.d. Home [WWW Document]. Home. URL https://www.ruhrmuseum.de/en/home/ (accessed 12.18.18).

Studio BR, 1976. Note sull'attività di progettazione architettonica ed urbanistica del gruppo professionale, Capellini Stampatore.

UNESCO [WWW Document], 2018 . UNESCO. URL https://en.unesco.org/ (accessed 12.18.18).

Vecco, M., 2010. A definition of cultural heritage: From the tangible to the intangible. J. Cult. Herit. Vol. 11, pp. 321-324. https://doi.org/10.1016/j.culher.2010.01.006

Volk, R., Stengel, J., Schultmann, F., 2014. Building Information Modeling (BIM) for existing buildings Literature review and future needs. Autom. Constr. Vol. 38, pp. 109-127. https://doi.org/10.1016/j.autcon.2013.10.023

Zordan, M., 2006. L'architettura dell'acciaio in Italia. Gangemi Editore. 